\title{
MIDDLE CERVICAL GANGLION AND VERTEBRAL GANGLION- CONTROVERSIES UNVEILED
}

\author{
Vandana Latha Raveendran ${ }^{1}$, K. Girijakumari Kamalamma ${ }^{2}$
}

1Assistant Professor, Department of Anatomy, Government Medical College, Thiruvananthapuram, Kerala, India.

2Professor and HOD, Department of Anatomy, Sree Mookambika Institute of Medical Sciences, Kulasekharam, Tamilnadu, India.

\section{BACKGROUND}

\section{ABSTRACT}

Great divergences are there regarding the occurrence and nomenclature of Middle Cervical Ganglion (MCG) and Vertebral Ganglion (VG) in human cervical sympathetic chain. The lack of a detailed knowledge of its branching pattern and vascular relations will lead to iatrogenic injury complicating many surgical procedures in the neck.

\section{MATERIALS AND METHODS}

The study was done on 50 cervical sympathetic chains by bilateral neck dissection of 25 adult cadavers in the Department of Anatomy, Medical College, Thiruvananthapuram. The vascular relations, branches and dimensions of Superior Cervical Ganglion (SCG), Inferior Cervical Ganglion (ICG), Stellate Ganglion and other intermediate ganglia were carefully dissected out and studied.

\section{RESULTS}

SCG was seen in $100 \%$ cases, Inferior Cervical Ganglion (ICG) in $72 \%$ cases and stellate ganglion in $28 \%$ chains. Out of the two intermediate ganglia between SCG and ICG, one seen in close relation to Inferior Thyroid Artery (ITA) was concluded as MCG $(44 \%)$ and another ganglion which was always over vertebral artery was concluded to be VG (72\%). The branches arising from the ganglia were Gray Rami Communicantes (GRC), vascular branches and medial visceral branches. Vertebral nerve from VG was present in $5.6 \%$ cases.

\section{CONCLUSION}

The VG is more frequently present than MCG. Also, comparative studies between the dimensions of MCG and VG when seen alone or together show no significant relation suggesting that both are independent ganglia and one is not a detached part of another.

\section{KEY WORDS}

Cervical Sympathetic Chain, Cervical Sympathetic Ganglia, Middle Cervical Ganglion, Vertebral Ganglion, Vertebral Nerve.

HOW TO CITE THIS ARTICLE: Raveendran VL, Kamalamma KG. Middle cervical ganglion and vertebral ganglion- controversies unveiled. J. Evolution Med. Dent. Sci. 2018;7(38):4167-4172, DOI: 10.14260/jemds/2018/932

\section{BACKGROUND}

The cervical sympathetic chain lies ventral to the transverse process of the cervical vertebrae and dorsal to the carotid vessels. It extends from the base of the skull to the level of the neck of first rib, where it continues as the thoracic sympathetic chain. A very generalised picture of a classical chain with 3 ganglionated masses named as superior cervical ganglion, middle cervical ganglion and inferior cervical ganglion or cervicothoracic ganglion is obtained from the previous studies, while little is mentioned about the existence of a fourth cervical ganglion or vertebral ganglion.

The terms to be used for the sympathetic nervous system were fixed by the International Anatomical Nomenclature Committee [Nomina Anatomica, Paris (1955)] where the term "truncus sympatheticus" was followed by the names of its ganglia, "ganglia trunci sympathetic." The ganglia in the cervical region were named as "ganglion cervical medium" and "ganglion cervicothoracicum" or "ganglion stellatum."

'Financial or Other Competing Interest': None.

Submission 04-08-2018, Peer Review 31-08-2018,

Acceptance 07-09-2018, Published 17-09-2018.

Corresponding Author:

Dr. Vandana Latha Raveendran,

Assistant Professor,

Department of Anatomy,

Government Medical College,

Thiruvananthapuram,

Kerala, India.

E-mail:drvandanalr@gmail.com

DOI: $10.14260 /$ jemds/2018/932
The term "ganglion vertebrale" was listed under the heading "ganglion cervical medium" without further explanation. ${ }^{1}$ Mannu denoted all ganglia between superior cervical ganglion and inferior cervical ganglion as "intermediate ganglia." 1 Matsui had used the term "intermediate ganglion" as a synonym of "middle cervical ganglion."1 Axford observed two ganglia between the superior cervical and the inferior cervical ganglia and referred this as "high and low middle cervical ganglia." $2 \mathrm{He}$ described the lower one as a detached portion of either the middle or the inferior ganglion.

Surgical procedures related to cervical sympathetic chain are common like thoracoscopic cervical sympathectomy for palmar hyperhidrosis, anterior cervical spinal surgeries 3,4 and ultrasound guided neck procedures like stellate ganglion block for chronic pain syndromes. ${ }^{5}$ Awareness of the regional anatomy of cervical sympathetics may help the surgeons in identifying and preserving this structure during related surgical procedures. The present study aims to define MCG and VG by tracing its vascular relations, dimensions and branches. The frequency of occurrence of these ganglia, which is surgically significant is also studied.

\section{MATERIALS AND METHODS}

25 formalin fixed adult cadavers from the Department of Anatomy, Medical College, Thiruvananthapuram were used for the study. A descriptive study of 50 cervical sympathetic chains over a period of 2 years was conducted with appropriate ethical approval from the Ethics Committee of the Medical College, Thiruvananthapuram. Carotid sheath 
was dissected in the anterior triangle following the conventional dissection steps. Cervical sympathetic chain was exposed deep to the sheath from the base of skull to the level of neck of second rib. All the ganglia seen and their branches were dissected taking care to preserve all its finer connections with the help of a head loupe of $2 x$ magnification. Length, breadth and thickness of ganglia were measured with vernier calipers. Various parameters like shape, location, branches, vascular relations and communications of all cervical ganglia were noted. All the measurements were tabulated.

\section{Statistical Analysis}

The mean and standard deviation of the length and breadth of MCG and VG were assessed. Correlation analysis was done to know the relation between VG length and MCG length and between VG breadth and MCG breadth. Pearson correlation was used to calculate the correlation coefficient.

\section{RESULTS}

A ganglionated cord was observed in all the specimens studied, lying over the longus colli muscle extending from the base of skull to the level of neck of first rib. The presence of SCG was a constant finding in all cases. In $72 \%$ cases, it was seen over the transverse process of second and third cervical vertebrae giving GRC to first 4 cervical spinal nerves. Between the SCG and ICG/ stellate ganglion, two ganglia were noted in varying frequency with definite vascular relations.

The higher one was present in 22 (44\%) cases and was related to ITA either anteriorly (22.7\%) (Fig. 6), posteriorly (50\%) (Fig. 2), superiorly (13.6\%) (Fig. 3) or inferiorly (13.6\%). The length, breadth and average thickness were $0.86+/-0.5 \mathrm{~cm}, 0.41+/-0.2 \mathrm{~cm}$ and $0.2 \mathrm{~cm}$ respectively. The shape varied from oval $(68.2 \%)$, irregular $(13.6 \%)$, fusiform $(13.6 \%)$ and round (4.6\%). Most frequently, it was found at the level of sixth cervical vertebral body $(50 \%)$.

\section{Lateral Branches/ (GRC)}

Gray ramus to $6^{\text {th }}$ cervical spinal nerve was seen in 7 (31.8\%) cases and to $5^{\text {th }}$ and $6^{\text {th }}$ cervical spinal nerves in $27.3 \%$ cases. No GRC in $6(27.3 \%)$ cases.

\section{Medial Branches}

Tracheo-oesophageal branches, 1 or 2 in number, were seen in $17(77.3 \%)$ cases. Cardiac branches were present in 19 (86\%) cases (Fig. 4).

\section{Vascular Branches}

1 - 2 branches were seen forming plexus over inferior thyroid artery in all the 22 cases.

The lower one was observed in 36 (72\%) cases, frequently at $7^{\text {th }}$ cervical vertebral body level. In $100 \%$ cases, it was closely related to vertebral artery forming plexus over it (Fig. 1 and 2). It was irregular in shape in all the 36 cases. The length, breadth and the thickness were $0.84+/-0.4 \mathrm{~cm}$, $0.5+/-0.2 \mathrm{~cm}$ and $0.2 \mathrm{~cm}$ respectively.

\section{Lateral Branches}

The GRC to the seventh cervical spinal nerve was seen in $38.9 \%$ cases. In 2 cases, vertebral nerve was seen arising and entering the foramen transversarium of $6^{\text {th }}$ cervical vertebrae along with the vertebral artery (Fig. 5).

\section{Medial Branches}

Tracheo-oesophageal branches were seen in 3 cases and cardiac branches in 18 cases. The cardiac branches descended to thorax directly and in 12 cases they joined with that from SCG or from trunk. In 3 cases, they formed plexus close to the root of neck (Fig. 1).

\section{Vascular Branches}

Vascular branches forming plexus over the vertebral artery were present in all the 36 cases (Table 1 and 2).

Thus out of 50 cervical sympathetic chains studied, the higher one was seen in 22 cases, lower one in 36 cases and together in a single chain in 11 cases (Fig. 2 and 4). There was an apparent fusion between the two ganglia in 1 case. A negative correlation was there between the length of both ganglia with correlation coefficient, $r=-0.354$. Also, negative correlation between the breadth of both ganglia was observed with negative coefficient, $r=-0.587$. The length of higher one in cases where it was present alone and where both were present were compared by applying Pearson correlation test and the p-value was 0.113 . The length of lower one in cases where it was present alone and where both were present were also compared by Chi-square test and the p-value was 0.965. In both the situations the differences between means were not statistically significant.

Cord below middle ganglia was seen double in all the cases studied. The anterior cord encircling the subclavian artery, ansa subclavia was observed in all the 50 cases. It was seen arising from the lower one in $70 \%$ cases (Fig. 4) and from the higher in $14 \%$ cases (Fig. 6), winding round the first part of the subclavian artery and getting connected to the ganglion below. In cases where both were present, the ansa originated from lower one in $91 \%$ cases (Fig. 4). The posterior cord was seen extending posterior to the subclavian artery as the continuation of the cervical sympathetic chain from the lower pole of ganglion above (higher or lower) to the upper pole of ganglion below (ICG or stellate ganglion). The average length of it was $0.78 \mathrm{~cm}$. No gray ramus or branches were seen originating from this.

Statistically, no significant size difference of VG was seen in these two types of occurrence. The same findings hold for MCG also, when present alone or when associated with VG. The MCG and VG were approximately equal in size with 0.5 to $1 \mathrm{~cm}$ in length. The length measurements were independent of the presence or absence of the other ganglion. Also, VG was a more frequent ganglion than MCG and together they were present in $22 \%$ cases. With these observations, VG could be considered as a constant entity within the cervical sympathetic chain.

\begin{tabular}{|c|c|c|}
\hline & $\begin{array}{c}\text { Higher Ganglion } \\
\text { (22 Cases) }\end{array}$ & $\begin{array}{c}\text { Lower Ganglion } \\
\text { (36 Cases) }\end{array}$ \\
\hline & C5 (9\%) & C6 $(22.2 \%)$ \\
GRC & C6 (31.8\%) & C7 $(38.9 \%)$ \\
& C5-C6 $(27.3 \%)$ & C5, C6, C7 $(2.8 \%)$ \\
& C5, C6, C7 (4.6\%) & Vertebral N (5.6\%) \\
& NIL (27.3\%) & Nil (27.8\%) \\
\hline Vascular & Over inferior & Over vertebral artery \\
Branches & thyroid artery (100\%) & $(100 \%)$ \\
\hline \multirow{2}{*}{ Medial } & Tracheo-oesophageal & Tracheo-oesophageal \\
Branches & (77.3\%) & $(8.3 \%)$ \\
& Cardiac (86\%) & Cardiac (50\%) \\
\hline \multicolumn{2}{|c|}{ Table 1. The Branching Pattern of Two Ganglia } \\
\hline \multicolumn{2}{|c|}{}
\end{tabular}




\begin{tabular}{|c|c|c|c|}
\hline Sl. No. & $\begin{array}{c}\text { GRC from } \\
\text { Higher One to }\end{array}$ & $\begin{array}{c}\text { GRC from } \\
\text { Lower One to }\end{array}$ & $\begin{array}{c}\text { GRC from } \\
\text { Cord to }\end{array}$ \\
\hline 1 & C6 & - & C5 \\
\hline 2 & 0 & C7 & C5, C6 \\
\hline 3 & C5, C6 & C7 & - \\
\hline 4 & C5, C6 & - & \\
\hline 5 & - & - & C5, C6 \\
\hline 6 & C5 & C6, C7 & - \\
\hline 7 & C6 & C7 & - \\
\hline 8 & - & C7 & - \\
\hline 9 & - & C6 & C5 \\
\hline 10 & C5, C6, C7 & - & - \\
\hline 11 & C5, C6 & C7 & - \\
\hline Table 2. The Origin of Gray Rami when both Ganglia seen \\
\multicolumn{4}{|c}{ together were as Follows } \\
\hline
\end{tabular}

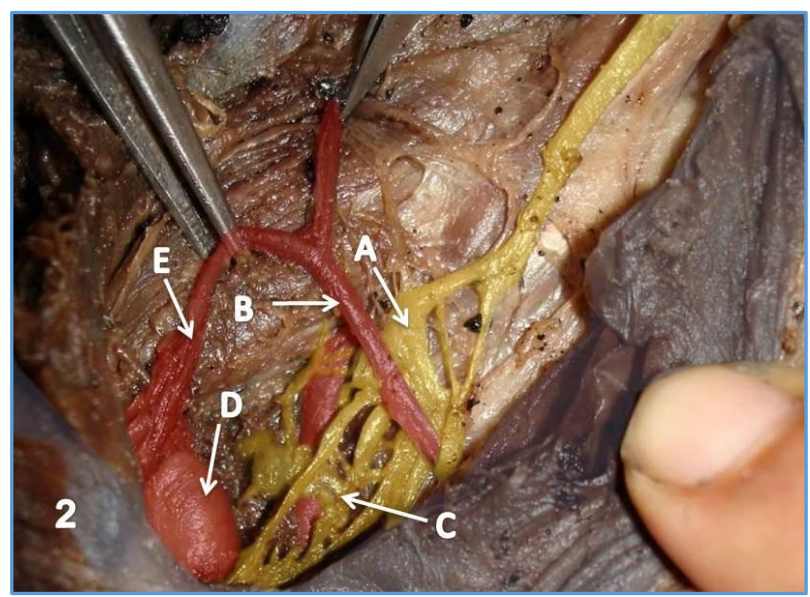

Figure 2. Right Cervical Sympathetic Trunk with both Middle Cervical and Vertebral Ganglion

A. Middle Cervical Ganglion

\begin{tabular}{|c|c|c|c|c|c|c|}
\hline & $\begin{array}{c}\text { No. of } \\
\text { Chains }\end{array}$ & $\begin{array}{c}\text { Only } \\
\text { MCG } \\
\text { (\%) }\end{array}$ & $\begin{array}{c}\text { Only } \\
\text { VG } \\
\text { (\%) }\end{array}$ & $\begin{array}{c}\text { MCG } \\
\text { +VG } \\
\text { (\%) }\end{array}$ & $\begin{array}{c}\text { Total } \\
\text { Chains } \\
\text { with VG } \\
\text { (\%) }\end{array}$ & $\begin{array}{c}\text { Total } \\
\text { Chains } \\
\text { with } \\
\text { MCG } \\
\text { (\%) }\end{array}$ \\
\hline $\begin{array}{c}\text { Kirgis and } \\
\text { Kuntz (1942) }\end{array}$ & 88 & - & - & - & $\mathbf{1 0 0}$ & 32 \\
\hline $\begin{array}{c}\text { Pick and } \\
\text { Sheehan } \\
(1946)^{6}\end{array}$ & 25 & 28 & 8 & 28 & 36 & 56 \\
\hline $\begin{array}{c}\text { Jamieson et al } \\
(1952)^{7}\end{array}$ & 100 & 64 & 36 & & & \\
\hline $\begin{array}{c}\text { Becker and } \\
\text { Grunt } \\
(1957)^{8}\end{array}$ & 114 & 7 & 32.4 & 55.3 & $\mathbf{8 7 . 7}$ & 62.3 \\
\hline $\begin{array}{c}\text { Canon Y et al } \\
(2009)^{9}\end{array}$ & 40 & 48 & 8 & - & - & - \\
\hline Present Study & 50 & 22 & 50 & 22 & $\mathbf{7 2}$ & 44 \\
\hline
\end{tabular}

Table 3. Reports on the Frequency of occurrence of Middle Ganglia

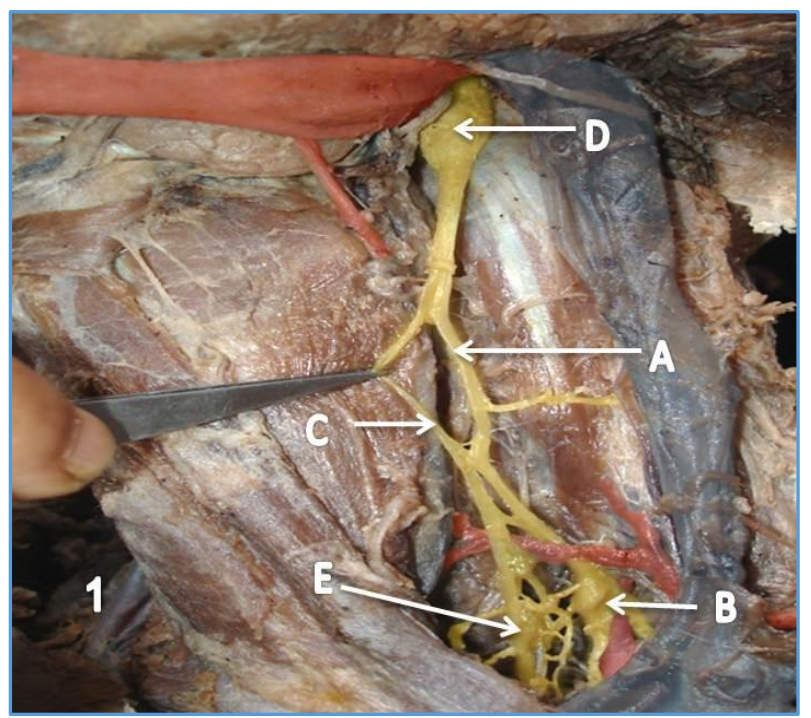

Figure 1. Left Cervical Sympathetic Trunk with Vertebral Ganglion

A. Cervical Sympathetic Trunk

B. Vertebral Ganglion over Vertebral Artery

C. Cardiac Branch from Trunk

D. Superior Cervical Ganglion

E. Ganglion in Cardiac Branch

B. Inferior Thyroid Artery (Anterior to MCG)
C. Vertebral Ganglion
D. Subclavian Artery
E. Thyrocervical Trunk

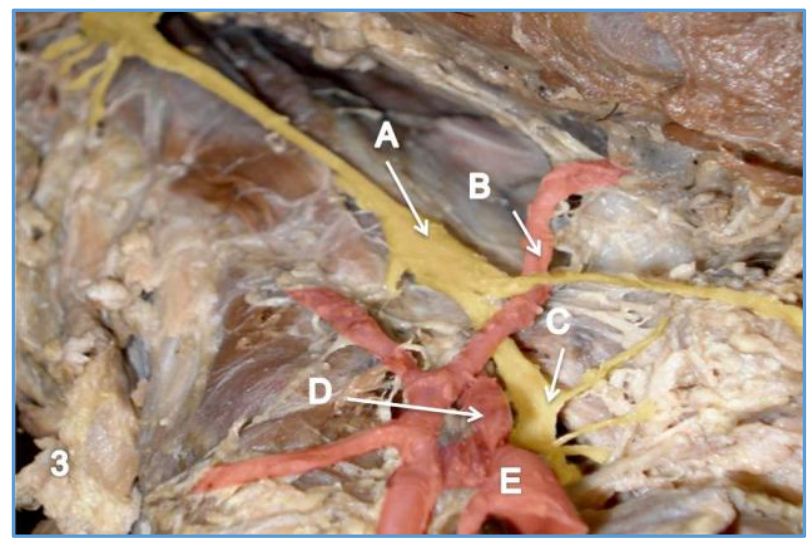

Figure 3. Left Cervical Sympathetic Trunk (Anteroinferior View) with Middle Cervical Ganglion
A. Middle Cervical Ganglion

B. Inferior Thyroid Artery (Inferior to MCG)

C. Inferior Cervical Ganglion

D. Vertebral Ganglion

E. Subclavian Artery

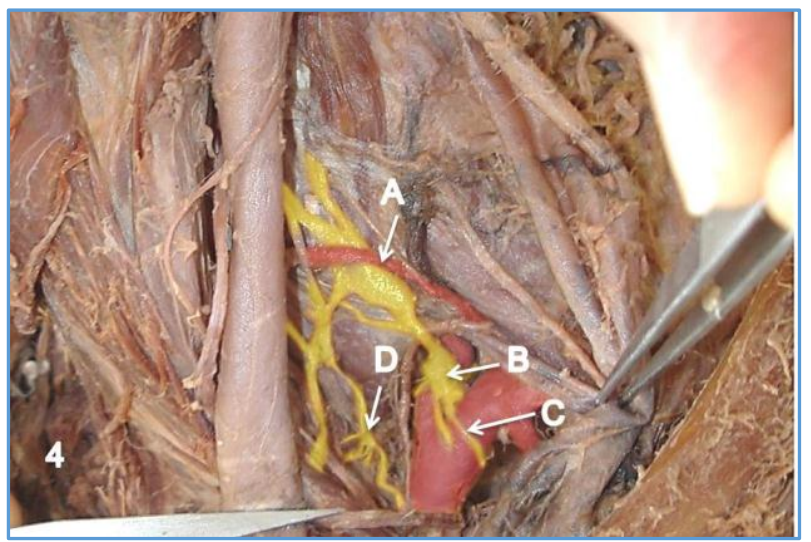

Figure 4. Left Cervical Sympathetic Trunk with both Middle Cervical and Vertebral Ganglion

A. Inferior Thyroid Artery (Anterior to MCG)

B. Vertebral Ganglion over Vertebral Artery

C. Ansa Subclavia from Vertebral Ganglion

D. Cardiac Branch from MCG 


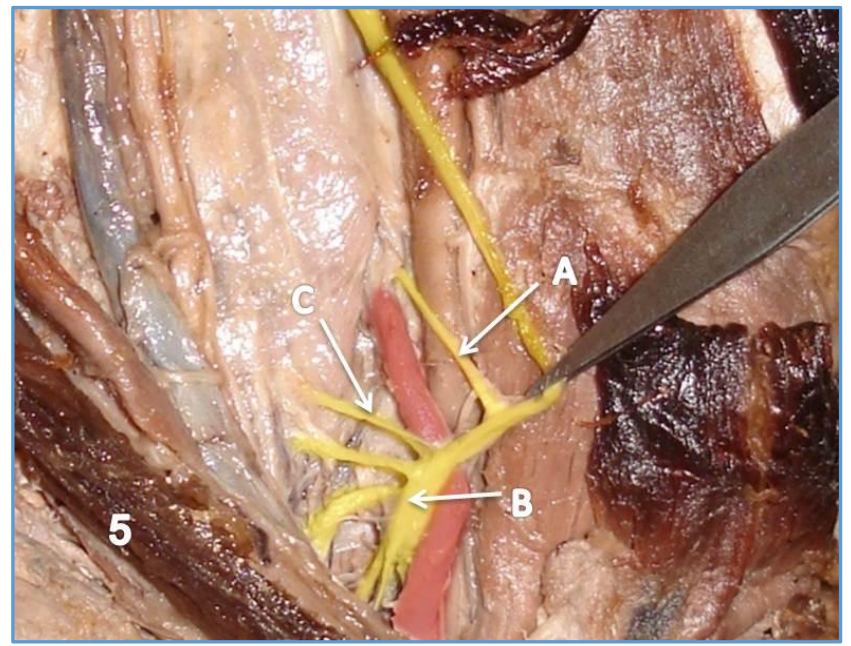

Figure 5. Right Cervical Sympathetic Trunk with Vertebral Ganglion

A. Vertebral Nerve.

B. Vertebral Ganglion.

C. Gray Rami Communicantes from Vertebral Ganglion.

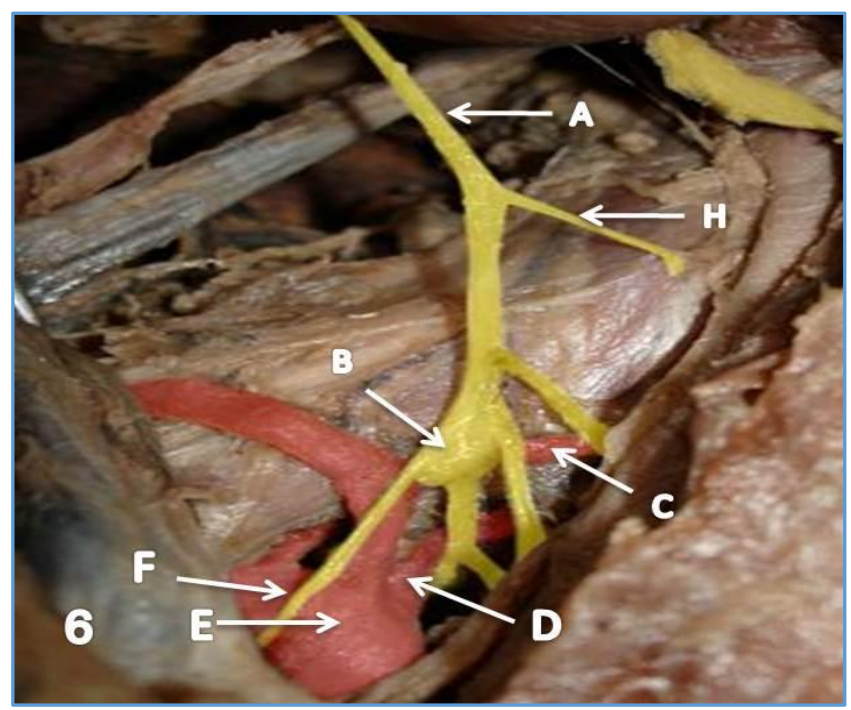

Figure 6. Right Cervical Sympathetic Trunk with Middle Cervical Ganglion

A. Cervical Sympathetic Trunk

B. Middle Cervical Ganglion

C. Inferior Thyroid Artery (Posterior to MCG) D. Vertebral Artery

E. Ansa Subclavia from MCG F. Subclavian Artery

\section{DISCUSSION}

The autonomic ganglia and nerves are related developmentally to central nervous system. Froriep and Hammond suggested their origin from the neural tube. ${ }^{10}$ Neural crest cells occupying the dorsolateral part of the neural tube form the primitive spinal ganglia, which differentiate to dorsal mass and ventral mass. The small cells of the ventral mass migrate laterally along the dorsolateral aspect of the primitive dorsal aorta and extend from the caudal cervical to the sacral region. These aggregates of cells were observed in human embryos of $6 \mathrm{~mm}$ in length. ${ }^{10}$ Wrete noted homogeneous ganglionated cords in $10 \mathrm{~mm}$ long human embryos. The segmental character of the sympathetic trunk is well marked below the cervical region in human embryos of $15 \mathrm{~mm}$ length and in the cervical region in embryos of $20-22 \mathrm{~mm}$ length, resulting in the clear demarcation of cervical sympathetic ganglia. Then the fibre bundles connecting them with one another are relatively free from cells and the sympathetic trunks have assumed a definite relationship to vertebral condensation. The development of the cervical sympathetic ganglia may get arrested at some stage and this leads to marked individual variations of the ganglia and its gray rami communicantes. ${ }^{1}$

SCG is considered to be formed by the fusion of first four cervical ganglia, MCG is by $5^{\text {th }}$ and $6^{\text {th }}$ and ICG is by fusion of $7^{\text {th }}$ and 8th cervical ganglia. If 1st thoracic ganglion contributes to $7^{\text {th }}$ and $8^{\text {th }}$ cervical ganglia, then results in stellate or cervicothoracic ganglion. The ganglia send gray rami to the corresponding spinal nerve. Woollard and Norrish noted the origin of GRC from the cord instead of its origin from the ganglia. ${ }^{11}$ In the present study, in $86 \%$ cases GRC were seen arising from the cord.

Many authors observed two ganglia in the middle of the cervical sympathetic chain and followed the terms "middle cervical ganglion" for the one that was related to inferior thyroid artery 5 and "vertebral ganglion" for the one that was related to vertebral artery. ${ }^{1}$ Sheehan used the term "thyroid ganglion" for the higher one, as it was related to the inferior thyroid artery. Hoffman and Kiray $A$ et al noticed the presence of both MCG and VG in the same sympathetic chain.12,13 In the present study, 11 cases had both ganglia in the single chain.

The findings of this study agree in that, "MCG is frequently absent and if present lies at the level of the $6^{\text {th }}$ cervical vertebra closely related to ITA." 11,14 Kuntz, Sheehan and Mitchell mentioned the frequent absence of MCG.2,10 In the present study, only $44 \%$ of cases showed MCG. Laubmann and Wrete had mentioned about the medio-superior cervical ganglion formed by the fusion of SCG and MCG. In the present study, in 2 cases long SCG with absence of MCG were noticed which could be considered as medio-superior cervical ganglion. Though a specific shape for MCG has not been mentioned, Kalsey G et al observed it as oval in 54.3\% cases studied.11 In the present study also, majority (68\%) of MCG were oval in shape. The range of measurements previously obtained were length $=0.5$ to $1.25 \mathrm{~cm}$, breadth $=0.25$ to 0.5 $\mathrm{cm}$ and thickness $=0.2$ to $0.5 \mathrm{~cm},{ }^{15}$ coinciding with the present study.

\section{Lateral Branches}

Many authors observed that the GRC to the $5^{\text {th }}$ and $6^{\text {th }}$ cervical spinal nerves occurred more frequently. The present study does not fully agree with this, as GRC to both C5 and C6 were seen in only $27.3 \%$ cases.

\section{Medial Branches}

Cardiac branches were reported from the ganglion or often arising from the trunk, cranial or caudal to the ganglion. But the present study showed the origin of this branch from the ganglion itself in $86.4 \%$ cases. The cardiac nerve from MCG had been described as the largest sympathetic cardiac nerve by Gray. ${ }^{12}$ Fine visceral branches to trachea and oesophagus were seen in the present study (77.3\%) in confirmation with the observation by Kalsey G et al. ${ }^{15}$ 


\section{Vascular Branches}

Over ITA were seen in all the cases as reported previously. 2,10

A small ganglion located anterior or anteromedial to the origin of vertebral artery from subclavian artery was considered a more constant ganglion than MCG. ${ }^{14}$ The present study also showed the increased frequency of VG $(72 \%)$ and $100 \%$ close relation to vertebral artery. An apparent fusion between MCG and VG was seen in $9 \%$ cases, which was mentioned earlier by Laubmann and Wrete as medio-vertebral cervical ganglion. ${ }^{1}$ In $63.9 \%$ cases, VG was seen close to the $7^{\text {th }}$ cervical vertebral body. Becker and Grunt noted the frequent locus of VG at the level of C7 in $87.7 \%$ of the chains studied. ${ }^{8}$ The range of measurements obtained coincided more or less with the values observed by Becker and Grunt and Kalsey $G$ et al, (which were summarised as length $=0.5$ to $1 \mathrm{~cm}$, breadth $=0.25$ to $0.7 \mathrm{~cm}$ and thickness $=0.2$ to $0.3 \mathrm{~cm}$ ).

\section{Lateral Branches}

Kuntz described the lateral branches as the GRC to the sixth and seventh cervical spinal nerves. Laubmann described VG as arising from the lower part of the $6^{\text {th }}$ cervical sympathetic ganglion and the GRC from VG to be connected to the $6^{\text {th }}$ cervical spinal nerve. ${ }^{1}$ But in the present observation, GRC was frequently being given to the 7 th cervical spinal nerve in about $38.9 \%$ cases in consistent with Kalsey G et al.

Vertebral nerve was mentioned as an additional GRC to the $6^{\text {th }}$ or $7^{\text {th }}$ spinal nerve from the MCG or VG or ICG or from the cord, but entering the foramen transversarium accompanying the vertebral artery.2,12,16 In the present study, it was seen arising from the upper pole of the VG in 2 cases and from the upper pole of ICG in 2 cases. Well-defined vertebral nerves were being described by many authors. ${ }^{15,17}$ Woollard and Norrish mentioned this as a constant finding arising from the connecting fibres between MCG and VG.

\section{Medial Branches}

Cardiac branches from VG were noted in $50 \%$ cases in confirmation with the earlier findings by Ellison and Williams. One to two tracheo-oesophageal branches were observed in $8 \%$ cases in the present study. Vascular branches forming plexus over the vertebral artery is observed in all the 36 cases coinciding with the observations of Kuntz and Kalsey $\mathrm{G}$ et al.

Two or more cords are seen connecting MCG/ VG to ICG. ${ }^{14}$ The anterior cord, ansa subclavia descends down looping the first part of the subclavian artery is in close contact with the cervical pleura. Kuntz and Becker and Grunt noted its frequent origin from VG (70\% in the present study). Ansa subclavia may arise from MCG or VG or from sympathetic cord itself. ${ }^{15,6}$ The posterior cord was seen extending below the MCG/ VG, posterior to the subclavian artery. It was seen enclosing the vertebral artery in $94 \%$ cases. So the term "ansa vertebrae" by Hoffman ${ }^{12}$ is appropriate.

From the data depicted in Table 3, it was obvious that the estimates on the frequency of occurrence of either type varied widely. In the present study, when only one ganglion was present in the middle of the CST, it was always seen anterior or anteromedial to the vertebral artery. This was said to be the vertebral ganglion. Also, VG (50\%) was found more often as the sole central mass than MCG (22\%). In this respect, the observation of the present study was nearly in line with those of Kuntz and Becker et al. Many authors had suggested that the VG merely represented a detached portion of MCG and its size was never inversely proportional to MCG, thus negating the notion that VG was a detached portion of MCG. ${ }^{11,15,18}$ In the present study it was noted that when VG present alone or when present with MCG, the average size of VG remained remarkably constant.

\section{CONCLUSION}

Four distinct ganglia were found along the cervical sympathetic chain, of which a ganglion at the level of the body of 7 th cervical vertebrae was more frequently encountered $(72 \%)$ than the classically described MCG at C6. The former gave origin to the ansa subclavia most frequently. The size of this particular ganglion did not show any statistically significant relation with the middle cervical ganglion. While MCG was seen in relation to the ITA, this fourth ganglion was closely associated with the root of vertebral artery in 100\% cases and to be concluded as the vertebral ganglion. Vertebral nerve was seen arising from VG in 5.6\% cases. GRC, visceral and vascular branches were given by almost all ganglia studied. If no gray ramus arises from ganglion, it was seen from the cord in $86 \%$ cases. Neurosurgeons and Anaesthetists must be aware of the more constant presence of vertebral ganglion at C6 vertebral level over vertebral artery to prevent its iatrogenic injury.

\section{REFERENCES}

[1] Wrete M. The anatomy of the sympathetic trunks in man. Journal of Anatomy 1959;93(Pt 4):448-59.

[2] Sheehan D. On the innervations of the blood vessels of the upper extremity: some anatomical considerations. British Journal of Surgery 1933;20(79):412-24.

[3] Yin Z, Yin J, Cai J, et al. Neuroanatomy and clinical analysis of the cervical sympathetic trunk and longus colli. Journal of Biomed Research 2015;29(6):501-7.

[4] Traynelis VC, Malone HR, Smith ZA, et al. Rare complications of cervical spine surgery: Horner's syndrome. Global Spine Journal 2017;7(Suppl 1):103S8S.

[5] Shin JE, Baek JH, Ha EJ, et al. Ultrasound features of middle cervical sympathetic ganglion. Clinical Journal of Pain 2015;31(10):909-13.

[6] Pick J, Sheehan D. Sympathetic rami in man. Journal of Anatomy 1946;80(Pt 1):12-20.3.

[7] Jamieson DW, Smith DB, Anson JB. The Cervical sympathetic ganglia. An anatomical study of 100 cervicothoracic dissections. Q Bull NorthWest Univ Med Sch 1952;26(3):219-27.

[8] Becker FR, Grunt JA. The cervical sympathetic ganglia. Anatomical Record 1957;127(1):1-14.

[9] Saylam CY, Ozgiray E, Orhan M, et al. Neuroanatomy of cervical sympathetic trunk: a cadaveric study. Clinical Anatomy 2009;22(3):324-30.

[10] Kuntz A. Development. Chap - 6. The autonomic nervous system. $4^{\text {th }}$ edn. Philadelphia: Lea and Febiger 1953: p. 117-9.

[11] Woollard HH, Norrish RE. The anatomy of the peripheral sympathetic nervous system. The British Journal of Surgery 1933;21(81):83-103. 
[12] Hoffman HH. An analysis of the sympathetic trunk and rami in the cervical and upper thoracic regions in man. Annals of Surgery 1957;145(1):94-103.

[13] Kiray A, Arman C, Naderi S, et al. Surgical anatomy of the cervical sympathetic trunk. Clinical Anatomy 2005;18(3):179-85.

[14] Ellison JP, Williams TH. Sympathetic nerve pathways to the human heart and their variations. American Journal of Anatomy 1969;124(2):149-62.

[15] Kalsey G, Mukherjee RN, Patnaik VVG. A comparative study of cervical sympathetic chain. Journal of Anatomical Society of India 2000;49(1):26-30.
[16] Kimmel DL. The cervical sympathetic rami and the vertebral plexus in the human fetus. Journal of Comparative Neurology 1959;112(1):141-61.

[17] Johal J, BelElary SS, Lax EA, et al. The vertebral nerve: a comprehensive review of its form and function. Journal of Clinical Neuroscience 2017;41:1-5.

[18] Standring S. Gray's Anatomy, Neck. The anatomical basis of clinical practice. 41st edn. London: Elsevier Publication 2015: p. 468-9. 